\title{
FITNESS COST ASSOCIATED WITH ACARICIDES INHERITANCE RESISTANCE IN THE SPIDER MITE, TETRANYCHUS URTICAE KOCH
}

\author{
ELEAWA, M. and WAKED, A. DALIA
}

Plant Protection Research Institute, ARC, Dokki, Giza, Egypt

(Manuscript received 31 March 2019)

\begin{abstract}

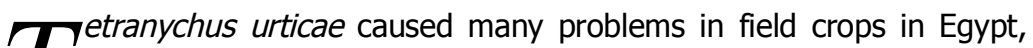
despite the use of acaricides that showed loss efficiency against $T$. urticae so we have studied bioassays tests for certain acaricides on some Egyptian strains of $T$. urticae. We investigated resistance levels of different acaricides from differ groups against $T$. urticae. Resistant Ratio $(R R), R R_{50}=119.62,19.53,17.93$ and 26.38 fold for fenpyroximate, chlorfenapyr, abamectin and bifenazate, respectively. The strain showed high levels of cross-resistance to abamectin (RR 152), moderate levels of cross resistance to chlorfenapyr (RR 38.08) and low levels of crossresistance $(R R<10)$ to bifenzate. Resistance coefficient $(R C)$ values calculated for this active ingredient 2.20 (medium resistance). Sensitivity of the mite to pyrrole and avermectin active ingredient 0.152 and 0.075 (lack of resistance). Carbazate was classified as 1.14 (low resistance). All acaricides shortened the longevity and decreased the fecundity of $T$. urticae resistance strain compared with the control. Life cycle of the offspring that produced from treated $T$. urticae females was increased in all treatments compared with the control.

Key words: Fitness cost, inheritance resistance, Tetranychus urticae
\end{abstract}

\section{INTRODUCTION}

Tetranychus urticae Koch (Acari: Tetranychidae), is considered the main pest which threaten the quality of many crops. Its short life cycle and abundant reproductive potential facilitate rapid resistance happening to many acaricides often after applications (Devine et al., 2001; Stumpf and Nauen 2001) use of repeated many acaricides for decades to control $T$. urticae continuously led to decrease the natural enemies populations that showed abundant of $T$. urticae population and resulted in appearance acaricides resistance (Kim, et al., 2004). So, widely resistance has been recorded in many countries for compounds, such as organophosphates (OPs) (Anazawa et al., 2003), fenpyroximate (Sato et al., 2004) and abamectin (Beers et al., 1998). This acaricide resistance has been a major deterrent in applied program integrated mite management in Egypt. In spite of, use fenpyroximate for short time in control T. urticae populations led to appear high levels of resistance (Cho et al. 1995), fitness cost related with acaricide resistance are where the promote of resistance to an acaricide is associated with high significant disadvantage that reduces the mite's fitness differentiate with its sensitive parallel in the population. Little studies have been done on cross-resistance types and resistance techniques in the acaricideresistant T. urticae, (Kim, et al., 2004) and each study is essential for the regional 
chosen of alternative acaricides for efficient resistance management. In this laboratory work we report on the cross-resistance types of fenpyroximate resistant $T$. urticae that considered the oldest acaricide in the local registration to three acaricides commonly used on field crops and resistance classification in Egypt. Fitness cost associated with resistance to acaricides have been reported in $T$. urticae.

\section{MATERIALS AND METHODS}

\section{Mass rearing of spider mite strains}

Abundant of $T$. urticae strains were taken from Zagazig region, Sharkia Governorate. In this study, two strains of T. urticae were used. The sensitive (S) strain has been preserved without offer to any acaricide in the laboratory for 4 months (Kim, et al., 2004). Resistant (R) strain had been created by selection pressure with $50 \mathrm{~g}$ litre ${ }^{-1}$ of acaricides for 20 successive generations. The two strains were fed on kidney bean seedlings ( 3 weeks after germination) in pots under the greenhouse conditions.

\section{Bioassay test}

Acaricides used in this study were obtained from plant protection research institute found in table (1), The acaricidal activity of the tested chemicals against adult females of the two strains was confirmed by a spray method technique.

Table 1. List of used acaricides

\begin{tabular}{|l|l|l|l|}
\hline Group & Common name & Trade name & Chemical name (IUPAC) \\
\hline Pyrazole & Fenpyroximate & Ortus 5\% Sc & $\begin{array}{l}\text { 1-(6-chloro-3-pyridylmethyl)-N- } \\
\text { nitroimidazolidin-2-ylideneamine. }\end{array}$ \\
\hline Avermectin & Abamectin & $\begin{array}{l}\text { Challenger 24\% } \\
\text { Sc }\end{array}$ & $\begin{array}{l}\text { 4-bromo-2-(4-chlorophenyl)-1- } \\
\text { (ethoxymethyl)-5-(trifluoromethyl) } \\
\text { pyrrole-3-carbonitrile }\end{array}$ \\
\hline Carbazate & Bifenzate & Acramite 48\% Sc & $\begin{array}{l}\text { 2-[-butan-2-yl]-dihydroxy-5-hydroxy- } \\
\text { 4-methoxy-6-methyloxan-2-yl] oxy-4- } \\
\text { methoxy-6-methyloxan-2-yl] oxy-3- } \\
\text { tetramethylspiro [2,3-dihydropyran- } \\
\text { trioxatetracyclopentacosa-tetraene }]\end{array}$ \\
\hline
\end{tabular}

Leaf discs (3 cm diameter) were taken from 3-weeks-old age leaves. Adult females of $T$. urticae were delivered onto a leaf disc on a cotton pad in Petri dish $(5.5 \times 2 \mathrm{~cm})$ the prepare four concentrations from each acaricide to calculate $L C_{50}$ values for two strains. $L C_{50}$ and $L C_{90}$ values and $95 \%$ confidence limits were calculated from Probit Analysis (Finney 1971). A resistance ratio (RR) was calculated according to the formula: 


\section{$\mathrm{LC}_{50}$ value for resistant strain}

$\mathrm{RR}=$

\section{$\mathrm{LC}_{50}$ value for sensitive strain}

RR values were classified as low $(<10)$, moderate, (10-40), high $(40-160)$ and extremely high resistance (>160), respectively. (Kim, et al., 2004). The resistance coefficient (RC) was calculated as follows:

$\mathrm{LC}_{95}(\mathrm{ppm})$

$\mathrm{RC}=$

$$
\text { Recommended field concentration (ppm) }
$$

The following criteria were assumed to assess resistance according to (Wegorek, et al. 2011):

$\mathrm{RC} \leq 1$ - lack of resistance,

$\mathrm{RC}=1.1-2-$ low resistance,

$\mathrm{RC}=2.1-5-$ medium resistance,

$\mathrm{RC}=5.1-10-$ high resistance,

$\mathrm{RC}>10$ - very high resistance.

\section{Fitness cost}

A resistance strain was obtained when reared for 20 generations as explained above. These females were placed individually on plant discs, that removed after 24 hours of laying the eggs. The newly deposited eggs incubated until they become adult then calculate the life cycle of the offspring. The females placed once again on the discs of mulberry leaves to complete egg laying and calculate their longevity and fecundity. A sensitive strain was obtained after reared for 4 months and placed individually on the plant discs and followed up as previously to obtain the control treatment

\section{RESULTS AND DISCUSION}

The efficiency of 4 acaricides to the sensitive (S) and resistance (R) strains of T. urticae was tested by the spray technique (Table 2). The responses were differed according to the active ingredient for acaricide used. Abamectin has been one of the potent acaricide in maintained crops for a decade. The $\mathrm{R}$ strain was extremely resistant to fenproximate resistance ratio (RR) 119.62-fold, while, RR were 19.53, 17.93 and 26.38-fold for chlorfenapyr, abamectin and bifenzate, respectively. The $R$ strain appeared high levels of cross-resistance to abamectin (RR 152), moderate levels of cross resistance to chlorfenapyr (RR 38.08) and low levels of cross-resistance $(\mathrm{RR}<10)$ to bifenzate. Similar trends were found by (Kim et al., 2004) who showed that, the strain exhibited strong positive cross-resistance among acaricides. 
Table 2. Toxicity of 4 acaricides to the sensitive (S) and resistant (R) strains of Tetranychus urticae and cross- resistance of fenpyroximate to tested acaricides

\begin{tabular}{|c|c|c|c|c|c|c|c|c|c|}
\hline \multirow[t]{2}{*}{ Acaricides } & \multirow{2}{*}{$\begin{array}{l}\text { Mite } \\
\text { strains }\end{array}$} & \multirow{2}{*}{$\begin{array}{c}\mathrm{LC}_{50} \\
\left(\mathrm{mg} \text { litre }^{-1}\right)\end{array}$} & \multicolumn{2}{|c|}{$\begin{array}{l}95 \% \text { Confidence } \\
\text { limit }\end{array}$} & \multirow{2}{*}{$\begin{array}{c}\mathrm{LC}_{90} \\
\left(\mathrm{mg} \text { litre }^{-1}\right)\end{array}$} & \multicolumn{2}{|c|}{$\begin{array}{l}95 \% \text { Confidence } \\
\text { limit } \\
\end{array}$} & \multirow[t]{2}{*}{ Slope } & \multirow{2}{*}{$\begin{array}{l}\mathrm{RR}_{50} \\
\text { (fold) }\end{array}$} \\
\hline & & & Lower & Upper & & Lower & Upper & & \\
\hline \multirow{2}{*}{ Fenpyroximate } & S-strain & 0.67 & 0.41 & 0.90 & 51.90 & 49.13 & 55.02 & 1.31 & \multirow{2}{*}{119.62} \\
\hline & R-strain & 80.15 & 76.50 & 83.02 & 1010.13 & 1530.2 & 1701 & 1.22 & \\
\hline \multirow{2}{*}{ Chlorfenapyr } & S-strain & 1.07 & 0.96 & 2.08 & 2.87 & 2.37 & 3.11 & 0.90 & \multirow{2}{*}{19.53} \\
\hline & R-strain & 20.90 & 17.69 & 25.12 & 77.11 & 70.50 & 80.23 & 1.24 & \\
\hline \multirow{2}{*}{ Abamectin } & S-strain & 0.43 & 0.15 & 0.93 & 1.35 & 0.90 & 1.97 & 1.33 & \multirow{2}{*}{17.93} \\
\hline & R-strain & 7.71 & 4.05 & 11.19 & 22.50 & 19.14 & 26.75 & 1.25 & \\
\hline \multirow{2}{*}{ Bifenzate } & S-strain & 4.28 & 2.68 & 6.50 & 41.72 & 38.99 & 42.75 & 1.71 & \multirow{2}{*}{26.38} \\
\hline & R-strain & 112.93 & 98.50 & 120.72 & 283.65 & 265.06 & 300.79 & 1.90 & \\
\hline $\begin{array}{l}\text { Fenpyroximate+ } \\
\text { Chlorfenapyr }\end{array}$ & R-strain & 40.75 & 34.15 & 46.11 & - & - & - & 1.11 & 38.08 \\
\hline $\begin{array}{l}\text { Fenpyroximate+ } \\
\text { Abamectin }\end{array}$ & R-strain & 65.36 & 64.08 & 70.00 & - & - & - & 1.59 & 152.00 \\
\hline $\begin{array}{l}\text { Fenpyroximate+ } \\
\text { Bifenzate }\end{array}$ & R-strain & 46.87 & 43.74 & 48.50 & - & - & - & 1.42 & 8.87 \\
\hline
\end{tabular}

RR values of $<10,10-40,40-160$ and $>160$ were classified as low, moderate, high and extremely high resistance, respectively. According to Kim et al., (2004)

Table (3) indicated the only pyrazole active ingredient, to which $T$. urticae exhibited resistance was fenpyroximate. Resistance coefficient (RC) values calculated for the active ingredient 2.20 (medium resistance). Sensitivity of the mite to pyrrole and avermectin active ingredient 0.152 and 0.075 (lack of resistance). Carbazate was classified as 1.14 (low resistance). This study presents great differences between $T$. urticae resistance levels to active ingredients from different chemical groups (Zamojska et al., 2018) who classified the resistance levels according to resistance coefficient (RC).

Table 3. Resistance levels of T, urticae to acaricides

\begin{tabular}{|l|c|c|c|c|}
\hline Acaricides & $\begin{array}{c}\text { F.R.C } \\
\mathbf{( p p m )}\end{array}$ & $\begin{array}{c}\text { LC } \mathbf{9 5} \text { for } \\
\mathbf{R - S}(\mathbf{p p m})\end{array}$ & $\mathbf{R . C}$ & $\begin{array}{c}\text { Resistance } \\
\text { classification }\end{array}$ \\
\hline Fenpyroximate & 500 & 1100.72 & 2.20 & Medium resistance \\
\hline Chlorfenapyr & 600 & 91.35 & 0.152 & Lack of resistance \\
\hline Abamectin & 400 & 30.11 & 0.075 & Lack of resistance \\
\hline Bifenzate & 350 & 400.73 & 1.14 & Low resistance \\
\hline
\end{tabular}

F.R.C = Field recommended concentration

R-st $=$ Resistance strain

R.C. $=$ Resistance coefficient

Data in table (4) showed the undesirable modifications in biological and reproductive aspects that generally achieved by comparing life-trait variables between sensitive (control) and resistant individuals that treated with different acaricides which, means fitness cost. The parameters evaluated were adult longevity, fecundity, fertility, and life cycle of offspring. All 
acaricides shortened the longevity and decreased the fecundity of $T$. urticae resistance strain compared with the control. The females that treated with fenpyroximate appeared high resistance deposited high rate of eggs, 26.88 eggs while, the lowest rate deposited eggs for abamectin 8.58 eggs that was lack of resistance. Life cycle of $T$. urticae was increased in all treatments compared with control. Insects are offered to a different pressure factors in their environment, and, in many cases for insect pests to agriculture, one of these factors is toxic insecticides (Kliot and Ghanim,2012). Coping with the toxicity of insecticides can be costly illustrated in several behavioral and physiological mechanisms such actions are costly and may affect reproduction.

Table 4. Fitness cost associated with acaricides resistance in T. urticae

\begin{tabular}{|c|c|c|c|c|c|c|}
\hline \multirow[b]{2}{*}{$\begin{array}{l}\text { Active } \\
\text { ingredient }\end{array}$} & \multirow[b]{2}{*}{$\begin{array}{l}\text { Longevity } \\
\text { (days) }\end{array}$} & \multirow[b]{2}{*}{ Fecundity } & \multirow[b]{2}{*}{ Fertility\% } & \multicolumn{3}{|c|}{ Offspring duration (days) } \\
\hline & & & & $\begin{array}{c}\text { Incubation } \\
\text { period }\end{array}$ & $\begin{array}{c}\text { Immature } \\
\text { stages }\end{array}$ & $\begin{array}{l}\text { Life } \\
\text { cycle }\end{array}$ \\
\hline Fenpyroximate & $11.37 \mathrm{~b}$ & $26.88 \mathrm{~b}$ & 80.31 & 3.95 & 7.75 & $11.70 \mathrm{c}$ \\
\hline Chlorfenapyr & $5.86 \mathrm{~d}$ & $17.39 c$ & 73.52 & 4.23 & 9.53 & $13.76 \mathrm{~b}$ \\
\hline Abamectin & $9.42 c$ & $8.58 \mathrm{~d}$ & 67.11 & 4.65 & 11.34 & $15.99 a$ \\
\hline Bifenzate & $13.65 b$ & $20.61 c$ & 85.23 & 3.22 & 7.38 & $10.60 c$ \\
\hline Control & $18.54 a$ & $73.62 a$ & 98.69 & 3.23 & 6.74 & $9.97 d$ \\
\hline
\end{tabular}

In conclusion, the results showed that resistant strain of $T$. urticae occur in Egypt. The economic effect of this strain has been accompanied with high crop losses. Some of the traditional acaricides, such as abamectin, fenpyroximate, chlorfenapyr and bifenazate have lost certain of their activity. However, recently introduced acaricides still extend suitable control of these strains, and we must take care when apply those in a proper resistance management, to safeguard their future use. Therefore, the search for alternatives to traditional pesticides and their improved application remains crucial for future spider mite control. After studying the resistance classification, we suggested that the resistance of these acaricides will increased in the future. Many biological and physiological life history characters can be studied for knowing the presence of fitness costs in a mite population; however, it is not always possible to measure these features easily. Generally, there is also no harmony in the populations chosen when comparing resistant and sensitive strains.

\section{REFERENCES}

1. Anazawa Y.; Tomita T.; Aiki Y.; Kozaki T. and Kono Y. 2003. Sequence of a cDNA encoding acetylcholinesterase from susceptible and resistant two-spotted spider mite, Tetranychus urticae, Insect Biochem. Mol. Biol. 33: 509-514 
2. Beers E.H.; Riedl H. and Dunley J.E. 1998. Resistance to abamectin and reversion to susceptibility to fenbutatin oxide in spider mite (Acari: Tetranychidae) populations in the Pacific Northwest. J. Econ. Entomol. 91: $352-360$

3. Cho J.R.; Kim Y.J.; Ahn Y.J.; Yoo J.K. and Lee J.O. 1995. Monitoring of acaricide resistance in field collected populations of Tetranychus urticae (Acari: Tetranychidae) in Korea. Korean J Appl Entomol 31:40-45

4. Devine G.J.; Barber M. and Denholm I. 2001. Incidence and inheritance of resistance to METI-acaricides in European strains of the two-spotted spider mite (Tetranychus urticae) (Acari: Tetranychidae). Pest Manag. Sci. 57: 443-448

5. Finney D.J. 1971. Probit analysis. Cambridge University Press, Cambridge, England. P. 333

6. Kim Y.J.; Lee S.H.; Lee S.W. and Ahn Y.J. 2004. Fenpyroximate resistance in Tetranychus urticae (Acari: Tetranychidae): cross-resistance and biochemical resistance mechanisms. Pest Manag. Sci., 60:1001-1006

7. Kliot A. and Ghanim M. 2012. Fitness costs associated with insecticide resistance. Pest Manag. Sci., 68: 1431-1437

8. Sato M.E.; Miyata T.; da Silva M.; Raga A. de Souza and Filho M.F. 2004. Selections for fenpyroximate resistance and susceptibility, and inheritance, cross resistance and stability of fenpyroximate resistance in Tetranychus urticae Koch (Acari: Tetranychidae). Appl. Entomol. Zool. 39: 293-302

9. Stumpf N. and Nauen R. 2001. Cross-resistance, inheritance, and biochemistry of mitochondrial electron transport inhibitor-acaricide resistance in Tetranychus urticae (Acari: Tetranychidae). J. Econ. Entomol. 94: 1577-1583

10. Węgorek P.; Zamojska J. and Mrówczyński M. 2011. Susceptibility level of the colorado potato beetle (Leptinotarsa decemlineata Say) to chlorpyrifos and acetamiprid in poland and resistance mechanisms of the pest to chlorpyrifos. J. Plant Protection Research. 51 (3): 279 - 284

11. Zamojska J.; Dworzańska D. and Węgorek P. 2018. Susceptibility level of cabbage seed weevil (Ceutorhynchus assimilis Payk.) (Coleoptera: Curculionidae) to selected active ingredients of insecticides in Poland. Journal of Plant Protection Research, 58 (1): 73-82 
تكلفة الكفاءة المرتبطة بالمقاومة الموروثة

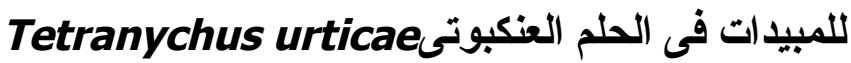

محمد عليوه محمد و داليا عبدالرحمن أحمد واكد

$$
\text { معهُ بحوث وقاية النباتات - مركز البحوث الزراعيةـ الدقى- الجيزهـ مصر }
$$

مع كثرة المشاكل التى تسببها الأكاروسات للمحاصيل الزر اعية كان يستوجب استخدام

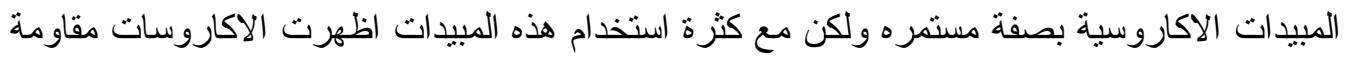
لهذه المبيدات مما ادى ذلك لانخفاض كفاءتها. تم در اسة مستويات المقاومة للمبيدات الاكاروسية المختبرة التى تتبع مجاميع مختلفة ضد الحلم

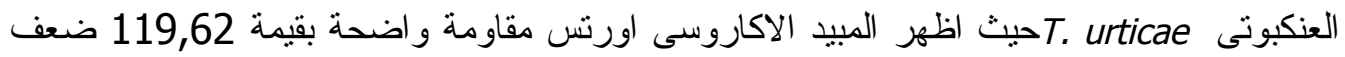
بينما كانت قيم المقاومة 19,53 ، 17,93 و 26,38 ضعف لكلا من الثنالنجر و الفيرتميك و الاكر اميت

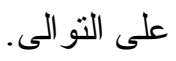

تم قياس استجابة السلالة المنتخبة مقارنة بالسلالة الحساسة وذلك للمبيدات سابقة الذكر حيث لم تظهر السلالة المنتخبة للاورتس اى مقاومة مشتركة مع الاكراميت حيث كانت نسبة المقاومة (RR)

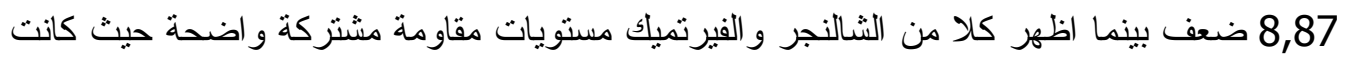

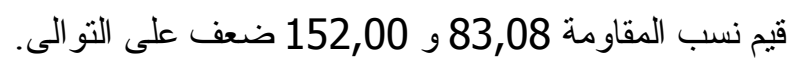

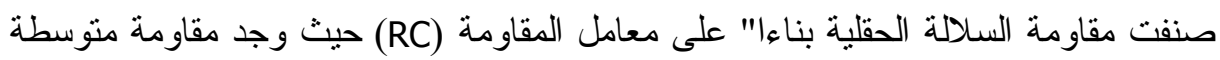
للاورتس بمعامل مقاومة 2,2 بينما كانت المقاومة قليلة للاكر اميت 1,14 وكانت قليلة جدا للثالنجر

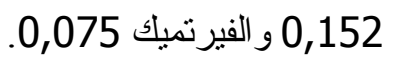

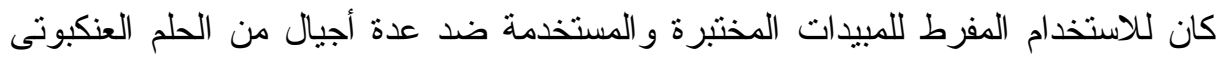
تأثثر سلبى فعال على حياة الافر اد المختبرة حيث ادى ذللك الى تدهور فى السلوك البيولوجى للحلم وتمثل فئل ذلك فى قلة معيشة الافر اد المعاملة ونقص خصوبتها بالاضافة الى زيادة فى دورة حياة الذرية الناتجة (مدة الوصول للطور البالغ) وذللك مقارنة بالكنترول. 
578

FITNESS COST ASSOCIATED WITH ACARICIDES INHERITANCE

RESISTANCE IN THE SPIDER MITE, TETRANYCHUS URTICAE KOCH 